\title{
Impact of Internal Control System Structures According to (COSO) Model on the Operational Performance of Construction Companies in the Gaza Strip: An Empirical Study
}

\author{
Iskandar M. Nashwan \\ ${ }^{1}$ Asst. Prof. of Accounting \& Auditing, Faculty of Management \& Finance, Al-Aqsa University Gaza, Palestine \\ Correspondence: Iskandar M. Nashwan, Asst. Prof. of Accounting \& Auditing, Faculty of Management \& \\ Finance, Al-Aqsa University Gaza, Palestine. E-mail: dr.eskandar.n@gmail.com
}

Received: August 20, 2018

doi:10.5539/ijbm.v13n11p176

\begin{abstract}
The construction sector is considered one of the most important sectors that support the economic development in any country as it helps in the development of the infrastructure, and affects the development of other sectors.

The study's main objective was to identify the impact of the internal control systems according to the (COSO) model with its elements (control environment, risk assessment, control activities, information and communication, monitoring and follow up) on the operational performance of construction companies in the Gaza Strip. Moreover, the current study aimed to examine the extent to which construction companies in the Gaza Strip comply with the internal control system structures according to the model with its elements.

In order to achieve the objectives of the study, it was implemented on (46) construction companies that operate efficiently and effectively in this sector and have organized financial and administrative systems governing their work. Therefore, the researcher designed a questionnaire for the study, which consisted of (49) paragraphs as a tool to collect required data, and was distributed to the sample of the study consisting of (460) individuals as (10) questionnaires were given to each company and retrieved (415) questionnaire valid for analysis (90.2\%). The researcher also used the descriptive analytical method.
\end{abstract}

After analyzing the results, the study found that there is a great commitment of constriction companies to the internal control structures of (COSO) model and there is a statistically significant positive effect for each of the elements of the model on the operational performance. Furthermore, the current study recommends that construction companies need to strengthen internal control systems that are efficient and effective by allowing the structures of their control systems to depend on the elements of the (COSO) model. Also, it recommends researchers to conduct further studies on other sectors such as services, trade and industry.

Keywords: internal control system, operational performance, construction companies

\section{Introduction}

Palestinians have been going through a series of circumstances that require searching for ways that can improve the performance of their economic sectors, which can alleviate their suffering in different areas. One of the most important sectors that constitute the most important pillars of the Palestinian economy is the construction sector. The construction sector accounts for $11.8 \%$ of Palestinian workers, and that makes it the largest in terms of the volume of annual investments, which reach an average of one billion dollars. Investment in housing, public and commercial buildings as well as infrastructure facilities (about 48\%) contributes to the total capital formation. Moreover, development of this sector has a strong impact on the development of other sectors, due to the intensity of its backward connections with construction input providers, and front-end connections with the providers of buildings with necessities needed for their use or operation (Palestinian Investment Promotion Authority, 2010).

In light of this importance that goes to the construction sector, as far as promoting of the Palestinian national economy is concerned, the Palestinian National Authority (PNA) has given a special importance to this sector since its establishment in May 1994. Hence, it has witnessed remarkable activity in the construction of housing, roads and schools, as well as the establishment of the infrastructure that the Gaza Strip has been lacking in 
throughout the years of unstable economic situation. A trade union body representing Palestinian contractors was formed to promote and develop the construction profession. Accordingly, the Palestinian Contractors Union was established and included the majority of companies operating in construction in the Gaza Strip.

Accordingly, and due to the highly important handling of contract activity in terms of accounting, the International Accounting Standards Board (IASB) has set forth International Accounting Standard (11) regarding the accounting treatment of revenue and costs in construction and construction contracts. The guidance of the standard shows the percentage of work performed on a cumulative basis for the current revenue and contract estimates for each period. Therefore, the effect of the expression on the estimation of the contract or its costs, or the effect of the expression on estimating the results of the contract is treated as an expression in the accounting estimates. In the meantime, preparing and presenting of financial statements of the construction companies occur according to First International Accounting Standard.

Based on the above, there must be regular and sound accounts and a sound internal control system for construction companies, because they represent the safety valve that protects the company's assets from misuse, and assures the use of available resources in the best possible way. It is clear now that in the modern environment, focusing on internal control as a system that helps to fairly present the items and elements of financial statements has really grown, and that extends to their role in reducing errors, fraud and manipulation that may occur in the financial statements.

The internal control system of any company is the first line in defense that protects the interests of shareholders in particular and all corporate-related parties, providing protection for the production of reliable financial information and making appropriate decisions in investment and credit (Juma ,2009). In addition to that, it is becoming a legal requirement to some countries after the financial crises, collapses and stalemates that hit the US economy and spread its effects to other countries. In light of this importance of internal control, several international professional bodies have shown great interest in the internal control systems and issued several bulletins and reports to define and evaluate the internal control system.

"The Committee of Sponsoring Organizations of the Treadway Commission" (COSO) is one major body of those, which aims at improving the quality of financial reports issued by institutions, as well as designing internal control systems that are comprehensive to all aspects of control. It defines internal control as "all the means and procedures used by the entity to protect its assets and to ensure the accuracy and exactness of accounting and statistical data to raise the productive efficiency in the company and achieve effectiveness (Al-Wardat, 2013). Moreover, the (COSO) Committee identified the most important concepts of the internal control system: (AlJard, 2013)

- Internal control is a process and a mean to achieve a goal.

- Internal control is carried out by qualified persons who are able to carry out their assigned role.

- Internal control provides only reasonable assurance and not absolute assurance to management and the board of directors.

- Internal control is designed and operated to achieve objectives effectively in several areas, depending on the understanding of management and its board of the extent to which those objectives are met.

\subsection{Internal Control Components (COSO)}

The International Auditing Standards Board (ISAC) (315) affirms that the division of internal control into five components provides a useful framework for auditors to cover various aspects of an entity's economic control. A considerable number of researchers, such as (Arens et al., 2014), (Husseini and Al-Sai'ri, 2017), (Al-Sayid, 2008), (Al-Bawab, 2015), (Ammar, 2015) agreed that these five compo-nents are: control environment, risk assessment, control activities, information and communication, monitoring and follow-up. These components can be represented as follows: 


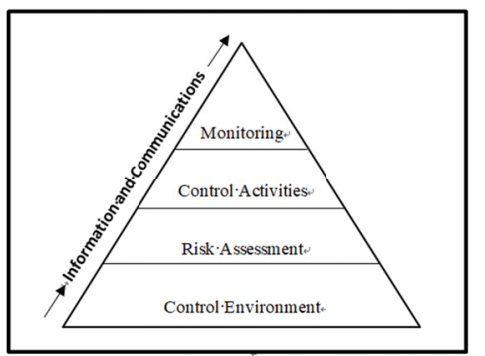

Figure 1. Internal Control Components (COSO)

The following is a presentation of each of these components:

1) The control environment: The control environment is the basic structure of all other components of internal control, i.e., the design and work of the control environment not only affects the general activity of the company, but also the other four elements of the control environment, and therefore an effective control environment has a direct effect on the success of internal control. (Chen \& Shi, 2012)

2) Risk assessment: The risk assessment process is a planned dynamic process that identifies and assesses risks springing from internal or external sources when achieving the objectives, and it constitutes a basis for identifying, managing and dealing with risks. As a proactive condition in identifying risks, objectives must be clearly defined and linked to levels in related units, thus making them capable of identifying and evaluating the risks associated with the objectives and how to deal with them. That is to add to detecting the possibility of fraud in the process of risk assessment during the achievement of the objectives.

3) Control Activities: The policies and procedures that aim to ensure compliance with administrative directives and ensure that the necessary procedures are taken to manage the risks facing the institution in achieving its objectives, such as performance audit, information processing, physical controls, segregation of duties.

4) Information and Communication: Information and communication component, is the component that connects each of the other components to each other, and the relevant information is identified and reported in the form and time frame that enables the staff to perform their responsibilities. In this sense, the sources of information may be internal, external, current, historical or anticipated (Harvey, 2008).

The purpose of this component is to identify, compile, classify, analyze and report on the financial operations of the economic unit and identify the liability for the associated assets (Dahdouh \&

Al-Qadi, 2012).

Accordingly, information is essential for the institution to carry out internal control responsibilities in order to support the achievement of its objectives. On the other hand, communication is a continuous and frequent process of providing, exchanging and obtaining the necessary information. Moreover, it contributes to the process of enabling individuals to receive a clear message from senior management regarding the need to take control responsibilities http://www.internalauditor.me/ar/article/cosos-internal-control-integrated-framework

seriously.

5) Monitoring: Monitoring means the continuous follow-up and periodic evaluation of the various components of internal control, determining whether they are functioning as required and determining the need for the necessary development and updating to keep pace with the circumstances and avoid the possibility of having obsolete internal controls. The information required for the assessment and updating process is derived from various sources, including the examination of the status of internal control, the reports of the internal auditor, the extraordinary reports on oversight activities, feedback from personnel work, complaints by debtors as well as the external auditor's observations.

\subsection{Study Problem}

In light of the punitive measures imposed on the Gaza Strip, such as the closure of borders and crossings and the imposition of a comprehensive siege, which negatively affects all aspects of life, especially the performance of companies operating in different fields. The construction sector in the current situation suffers from many problems such as weak domestic investments in construction due to poor economic conditions, and the state of siege and the lack of access to the requirements of building materials needed for this sector under the pretext of 
security, which caused the high cost of purchasing these materials, and the purchase and maintenance of equipment and operation. Construction companies in the Gaza Strip are facing the inability to continue, and the erosion of their capital as a result of the accumulation of losses without compensation for it, and the existence of fierce price competition, which leads to collapse or financial failure or declare bankruptcy.

As the internal control system is one of the elements of the success of companies in determining the progress of their work and the success of their activities and advancement towards achieving their desired goals, especially if working under very difficult environmental conditions such as the Palestinian environment, which is at a state of instability in all fields and at all levels. In view of the importance of construction companies and the large and pivotal role entrusted to them to rebuild the country after the destruction of many of its facilities and government and private facilities, as well as thousands of homes and infrastructure, as a result of the several wars launched on Gaza Strip in the last years. That is to add to the urgent needs of a huge number of housing units to meet the needs of people whose homes were destroyed.

As the construction companies are the most affected by these conditions, in addition to the occurrence of some abuses, whether financial or administrative, this sector of companies is in urgent need of an efficient control system, one which is effective and modern.

\subsection{Study Hypotheses}

1) The contractors in the Gaza Strip have no commitment to the structures of the internal control systems in accordance with the (COSO) model with its elements (control environment, risk assessment, control activities, information and communications, monitoring and follow-up).

2) There is no statistically significant effect on the implementation of the control environment component according to the (COSO) model on the operational performance of construction companies in the Gaza Strip.

3) There is no statistically significant effect of applying the risk assessment component in accordance with the (COSO) model on the operational performance of construction companies in the Gaza Strip.

4) There is no statistically significant impact of the implementation of the control activities component in accordance with the (COSO) model on the operational performance of construction companies in the Gaza Strip.

5) There is no statistically significant impact of the implementation of the information and communication component in accordance with the (COSO) model on the operational performance of construction companies in the Gaza Strip.

6) There is no statistically significant impact on the implementation of the monitoring and follow-up component in accordance with the (COSO) model on the operational performance of construction companies in the Gaza Strip.

\subsection{Study Objectives}

1) Identify the extent to which construction companies in the Gaza Strip comply with the internal control system structures according to the (COSO) model with its components: (control environment, risk assessment, control activities, information and communications, monitoring and follow-up).

2) Measuring the statistical significance of the application of the internal controls according to the (COSO) model on the operational performance of construction companies in the Gaza Strip.

\subsection{Importance of the Study}

1) The importance of the problem that is dealt with. The construction sector is considered one of the important economic sectors in Palestine due to its role in promoting the economic activity. In addition, this study contributes to the development of the operational performance of construction companies in the Gaza Strip.

2) Focus on the pivotal role of internal control in accordance with the (COSO) model to show how it affects the operational performance of the construction companies in the Gaza Strip, thus increasing the confidence of its users in making the appropriate decisions, thus protecting their resources and assets and implementing their development programs and plans with great success .

3) The need of the Arab and Palestinian scientific library for such study due to the lack of researches in the field of internal control according to the (COSO) model in connection with the operational performance of construction companies in the Gaza Strip.

4) This study provides measuring tools that can be used by other researchers. 


\section{Previous Studies \& Research}

Based on the above information that shows the importance of the (COSO) model as the basis of the modern approach to control, the (COSO) model has been addressed in research and investigation by many researchers to try to find out its effect on a number of related accounting variables.

The study of Abu-Miala (2017) sought to identify the impact of the structure of internal control systems according to the (COSO) model on improving the quality of the performance of the external audit, and used a questionnaire that was distributed to a sample of (90) auditors. The main results of the study were that there was an impact of the structure of the internal control systems according to the (COSO) model on improving the quality of the performance of the external audit. The results also indicated that there is a great degree of commitment by the public shareholding companies listed on the Palestine Stock Exchange to the structure of internal control systems in their fields risk assessment, control activities, information and communications, monitoring and follow-up.

Another study was conducted by Lozon (2016) to evaluate the effectiveness of the role of internal auditing and its role in evaluating risk management according to the (COSO) framework. In order to achieve the objectives of the study and test its hypotheses, a questionnaire was designed and distributed to a sample of (71) of the respondents working in the Internal Audit Department and the Finance Department in the government sectors. One of the main results of the study indicated a lack of regulations governing internal audit performance that play a role in evaluating risk management in the government sectors in the Gaza Strip. In addition to that, there was an absence of the active role of the internal audit dedicated to reviewing the techniques used to identify the risks and opportunities related to the effectiveness of its role in monitoring the implementation of control measures in the governmental sector.

In this sense, the Mushtaha study (2015) sought to assess the extent to which internal control systems in Palestinian public shareholding companies were consistent with the (COSO) model, as well as the impact on the company's performance and value. To achieve this, a questionnaire was applied to the study sample of (40) public shareholding companies listed on the Palestine Stock Exchange. The study found that the internal control systems applied in the public shareholding companies in Palestine are highly consistent with the (COSO) model . In addition, there is a statistically significant impact on the application of the control components according to the (COSO) model on the financial performance indicators of companies listed on the Palestine Stock Exchange.

Moreover, (Ayager et al.,2014) examined the evaluation of internal control systems followed by banks in Ghana and the control activities used under the (COSO) framework. Here, a questionnaire was prepared and distributed to a sample of 30 senior managers and audit managers in banks in Ghana. The results of the study indicated strong controls in the control environment and supervisory activities of Ghanaian banks.

In the same context, Badawi study (2011) aimed at identifying the impact of the structure of the internal control system in accordance with the (COSO) model on achieving the monitoring objectives of the NGOs operating in the Gaza Strip and identifying the development of the structure of the internal control systems in these organizations. To achieve this, the study was conducted on a sample of (99) NGOs in the Gaza Strip working in different developmental and social fields. The descriptive analytical method was used in the comprehensive inventory method. The most important results of this study indicate a presence of great interest by NGOs operating in the Gaza Strip with internal control systems. It was also found that NGOs consider varying positive degrees of the importance of the elements of the internal control system in achieving the oversight objectives of achieving the effectiveness and efficiency of operational activities, the credibility of financial reports and the promotion of compliance with laws and regulations.

Still, the Muraleetharan (2009) study highlighted the contribution of (COSO's) internal control system to the increased financial performance of enterprises. The study sample consisted of 181 Sri Lankan companies. The study found that the performance of institutions in general is related to the internal control applied as well as the financial performance. It also found a statistically significant impact of internal control on financial performance, and that the effective application of internal controls (risk assessment, control activities, monitoring and follow-up) will improve financial performance better, while the rest of the internal controls (control environment, information and communication) have no impact on financial performance.

\subsection{Research Gaps}

Through reviews of the previous studies carried out by other researchers, it has been found that there is a consensus among them concerning the importance of the role of the internal control system in companies, banks and other institutions in different fields, thus the research gaps can be concluded as follows: 
1) Spatial Gap: There is no local study on the subject. The current study was applied to the construction sector in the Palestinian environment.

2) Substantive Gap: The lack of studies that linked the studied variables. The independent variables (internal control elements according to the COSO model) and the dependent variable, which is the operational performance of the construction companies.

3) Standard Gap: There is a difference in the method of measurement of the dependent variable, and different from some studies in the use of the study tool questionnaire.

\section{Study Variables}

In light of the problem of study and its objectives, and using the previous studies and research, the researcher prepared the study variables as well as the following figure (2), which illustrates the independent variables (internal control elements according to the (COSO) model) and the dependent variable, which is the operational performance of the construction companies.

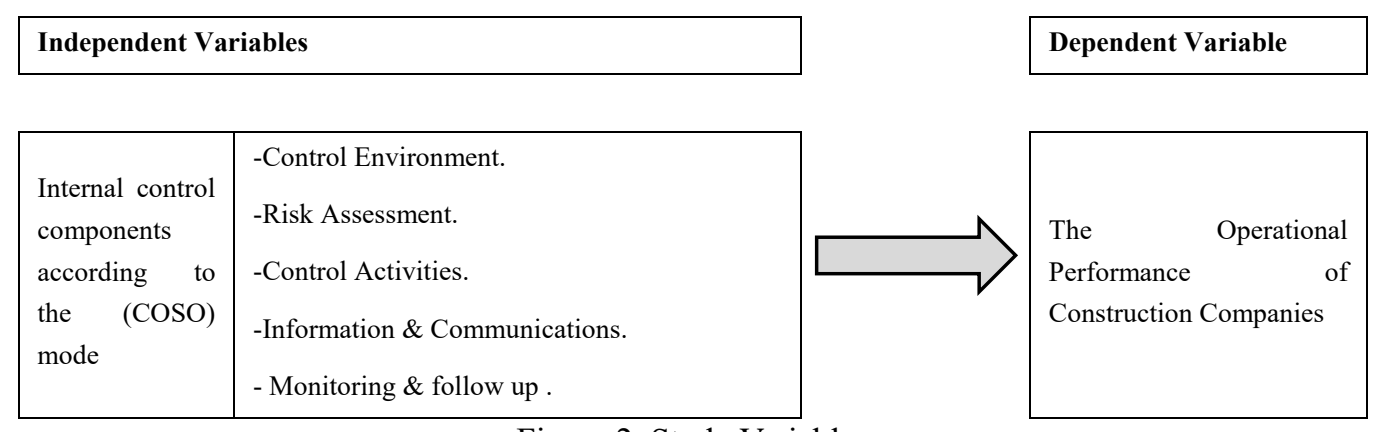

Figure 2. Study Variables

\section{Study Limits}

Study results are limited to the following limits

- Temporal Limits: The content and results of the field study are related to the time of the study, which was May and June 2018.

- $\quad$ Spatial boundaries: This study was limited to surveying the opinion of the study sample of the construction companies that are active in the southern governorates of the Palestinian National Authority (Gaza Strip).

- Human Boundaries: Accountants, Directors of Financial Supervision, Directors of Administrative Control, Financial Managers, and External Auditors.

- Objective limits: The objective limit is limited to internal control in accordance with the (COSO) model and its impact on the operational performance of construction companies in the Gaza Strip.

\section{Study Terms}

The researcher defined the procedural meanings of the terms used in the study as follows:

- Internal Control: The Organization of Treadway Committee of Sponsoring Commission (COSO) defines internal control as "all the means and procedures used by the entity to protect its assets and assets and to ensure the accuracy and accuracy of accounting and statistical data to increase the productive efficiency of the company and to achieve effectiveness (Al-Wardat 2014). The Committee has identified five key elements of internal control: regulatory environment, risk assessment, control activities, information and communications, monitoring and follow-up (Al-Bawab, 2015).

\section{Procedures}

The procedures are the main focus through which the practical aspect of the study is accomplished. The required data are obtained to conduct the statistical analysis to reach the results that are interpreted in light of the study literature related to the subject. These procedures included:

\subsection{The Methodology of the Study}

The researcher followed the analytical descriptive approach to address the purposes of this study. Accordingly, it depends on studying the phenomenon as it exists in reality and is concerned with providing a precise description that goes to both a quantitative and qualitative expression. However, this approach is not sufficient when it 
comes to collecting information related to the phenomenon in the course of investigating its manifestations and its different relations. Therefore, it extends to analysis, linkage and interpretation in order to reach conclusions on which the proposed scenario is based, and the necessity of increasing the knowledge base is addressed.

\subsection{Study Population and Sample}

According to the Contractors' Union in the Gaza Strip for 2017, the population of study comprised of (136) Construction Companies registered with the Contractors' Union.

Table 1. The study population of construction companies in the Gaza Strip

\begin{tabular}{lll}
\hline $\begin{array}{l}\text { Classification of } \\
\text { Construction Companies }\end{array}$ & Number & Percentage \\
\hline Companies still operating & 46 & $\% 33.8$ \\
Companies suspended from work & 90 & $\% 66.2$ \\
Total & $\mathbf{1 3 6}$ & $\mathbf{\% 1 0 0}$ \\
\hline
\end{tabular}

Construction companies of (46) companies were chosen intentionally for the study sample based on companies that are still operating in the construction sector in the Gaza Strip for the following reasons:

1. The size of these companies is large in the construction sector.

2. Categorized grade (A) in the field of work.

3. These companies have organized administrative and accounting systems.

The sampling unit and analysis (respondents) included (460) employees selected intentionally from the different areas in the target companies as (10) questionnaires were given to each company; to collect data from accountants, the directors of financial supervision, the directors of the administrative control, the financial managers, and the external auditors as well as financial, administrative and supervisory employees. Thus, 460 questionnaires were distributed, of which (415) were retrieved $(90.2 \%)$.

Table 2. Shows the number of questionnaire sent and the number of questionnaire analyzed

\begin{tabular}{lll}
\hline $\begin{array}{l}\text { Classification of } \\
\text { Questionnaires }\end{array}$ & Number of Questionnaires & Percentage \\
\hline Questionnaires sent & 460 & $\% 100$ \\
Questionnaires that have not been retrieved & 45 & $\% 9.8$ \\
Questionnaires analyzed & 415 & $\% 90.2$ \\
\hline
\end{tabular}

Table 3. Shows the number of study sample (respondents) according to the job description

\begin{tabular}{lll}
\hline Respondents & Number of Questionnaires & Percentage \\
\hline Accountants & 106 & $\% 25.3$ \\
Director of Financial Supervision & 39 & $\% 9.9$ \\
Director of Administrative Control & 45 & $\% 10.8$ \\
Financial Manager & 44 & $\% 10.7$ \\
External Auditor & 92 & $\% 22.6$ \\
Other Employees & 89 & $\% 20.7$ \\
Total Retrieved Questionnaires & $\mathbf{4 1 5}$ & $\mathbf{\% 1 0 0}$ \\
\hline
\end{tabular}

\subsection{The Study Tool}

The researcher prepared a questionnaire as a tool to identify the impact of internal control system structures according to the (COSO) model on the operational performance of construction companies in the Gaza Strip. The questionnaire consisted of five areas as follows:

The areas of the impact of the structures of the internal control systems according to the (COSO) model on the operational performance of construction companies in the Gaza Strip which consists of (49): 
Table 4. Areas of Questionnaire

\begin{tabular}{|c|c|c|}
\hline$\#$ & Areas & $\begin{array}{l}\text { Number of } \\
\text { paragraphs }\end{array}$ \\
\hline 1 & $\begin{array}{l}\text { The first area: the impact of the control environment according to the (COSO) model on the operational } \\
\text { performance of the construction companies }\end{array}$ & 10 \\
\hline 2 & $\begin{array}{l}\text { The second area: the impact of risk assessment in accordance with the (COSO) model on the operational } \\
\text { performance of the construction companies }\end{array}$ & 15 \\
\hline 3 & $\begin{array}{l}\text { The third area: the impact of control activities according to the (COSO) model on the operational performance of } \\
\text { the construction companies. }\end{array}$ & 9 \\
\hline 4 & $\begin{array}{l}\text { The fourth area : The impact of information and communication according to the (COSO) model on the } \\
\text { operational performance of the construction companies. }\end{array}$ & 9 \\
\hline 5 & $\begin{array}{l}\text { The fifth area: the impact of monitoring and follow-up according to the model of the (COSO) Committee on the } \\
\text { operational performance of the construction companies. }\end{array}$ & 6 \\
\hline
\end{tabular}

The five-layer Lycert Gradient (rare, low, medium, large, very large) was used according to the grades shown in Table (5).

Table 5. Degrees included in the Questionnaire

\begin{tabular}{llllll}
\hline Response & Rare & Low & Medium & Large & Very large \\
\hline Scale & 1 & 2 & 3 & 4 & 5 \\
\hline
\end{tabular}

\subsubsection{Relative Weight of Questionnaire Paragraphs}

To find the relative weight of the questionnaire paragraphs, these paragraphs were analyzed using the parameter tests ( $\mathrm{T}$ test for one sample), where grade (3) is considered neutral and represents $60 \%$ on the scale of research as shown Table 6.

Table 6. Grades of interpretation of answers according to arithmetic mean categories

\begin{tabular}{llll}
\hline Degree & Scale & Average & Relative weight \\
\hline Rare & $\mathbf{1}$ & $1.00-1.80$ & Less than $36 \%$ \\
Low & $\mathbf{2}$ & $1.80-2.60$ & from $35 \%-52 \%$ \\
Medium & $\mathbf{3}$ & $2.60-3.40$ & from $52 \%-68 \%$ \\
Large & $\mathbf{4}$ & $3.40-4.20$ & from $68 \%-84 \%$ \\
Very large & $\mathbf{5}$ & $4.20-5.00$ & from $84 \%-100 \%$ \\
\hline
\end{tabular}

\subsubsection{Validity of the Questionnaire}

The validity of the questionnaire is intended to measure the questions of the questionnaire, and the researcher verified the veracity of the questionnaire in two ways:

Arbitrators honesty (Virtual honesty): The researcher presented the questionnaire to a group of arbitrators composed of specialists in the academic, accounting and professional fields. The researcher responded to the opinions of the arbitrators and made the necessary deletion and modification in the light of the proposals presented. Thus, the questionnaire is in its final form.

The validity and reliability of the study questionnaire have been ascertained, making them reliable to analyze the results, and test its hypotheses.

Authenticity of internal consistency: The internal consistency is the consistency of each paragraph of the questionnaire as far as the area to which this paragraph belongs is concerned. The researcher calculated the internal consistency of the questionnaire by applying the questionnaire to a survey sample of 46 construction companies registered with the Contractors Union, though representing the construction sector outside the sample of the study, and then calculated the correlation coefficients of the responses of the survey sample members for each field. The results are as shown in the following table: 
Table 7. The Correlation Coefficient for each area of the questionnaire

\begin{tabular}{|c|c|c|}
\hline \#Area & $\begin{array}{l}\text { Pearson C } \\
\text { Correlation }\end{array}$ & $\begin{array}{l}\text { ofProbability } \\
\text { Value (Sig.) }\end{array}$ \\
\hline \multicolumn{2}{|c|}{$\begin{array}{l}\text { 1The impact of the control environment according to the (COSO) model on the operational0.747 } \\
\text { performance of the construction companies }\end{array}$} & 0.000 \\
\hline \multicolumn{2}{|c|}{$\begin{array}{l}\text { 2The impact of risk assessment according to the (COSO) model on the operational0.699 } \\
\text { performance of construction companies }\end{array}$} & 0.000 \\
\hline \multicolumn{2}{|c|}{$\begin{array}{l}\text { 3The impact of control activities according to the (COSO) model on the operational0.713* } \\
\text { performance of construction companies }\end{array}$} & 0.000 \\
\hline \multicolumn{2}{|c|}{$\begin{array}{l}\text { 4The impact of information and communication according to the (COSO) model on the } 0.708^{*} \\
\text { operational performance of construction companies. }\end{array}$} & 0.000 \\
\hline \multicolumn{2}{|c|}{$\begin{array}{l}\text { 5The impact of monitoring and follow-up according to the model of the (COSO) Committee } 0.768^{*} \\
\text { on the operational performance of construction companies }\end{array}$} & 0.000 \\
\hline
\end{tabular}

Note. $*$ The correlation is statistically significant at $0.05 \leq \alpha$.

It is clear from the results in Table 7 that there is a statistically significant correlation for each area of the questionnaire, which confirms the validity of the internal consistency of the question paragraphs.

\subsubsection{Stability of the Questionnaire}

The stability means consistency in the results of the questionnaire and it does not change significantly if distributed to individuals several times during certain periods of time .

The researcher verified the stability of the research questionnaire through the use of Cronbach's Alpha Coefficient and the half-split method, and the results were as shown in Table (8).

Table 8. Alpha Cronbach and half - split to measure the stability of the questionnaire

\begin{tabular}{|c|c|c|c|c|c|}
\hline \# & Areas & $\begin{array}{l}\text { Number of } \\
\text { Paragraphs }\end{array}$ & $\begin{array}{l}\text { Cronbach's } \\
\text { Coefficient }\end{array}$ & Alpha & Half-Split \\
\hline 1 & $\begin{array}{l}\text { The First Area: the impact of the control environment } \\
\text { according to the (COSO) model on the operational } \\
\text { performance of the construction companies. }\end{array}$ & 10 & 0.913 & & 0.777 \\
\hline 2 & $\begin{array}{l}\text { The Second Area: the impact of risk assessment in } \\
\text { accordance with the (COSO) model on the operational } \\
\text { performance of construction companies. }\end{array}$ & 15 & 0.931 & & 0.812 \\
\hline 3 & $\begin{array}{l}\text { The Third Area: the impact of control activities } \\
\text { according to the (COSO) model on the operational } \\
\text { performance of the construction companies. }\end{array}$ & 9 & 0.884 & & 0.810 \\
\hline 4 & $\begin{array}{l}\text { The Fourth Area: The impact of information and } \\
\text { communication according to the (COSO) model on the } \\
\text { operational performance of construction companies. }\end{array}$ & 9 & 0.879 & & 0.756 \\
\hline 5 & $\begin{array}{l}\text { The Fifth Area: the impact of monitoring and follow-up } \\
\text { according to the model of the (COSO) Committee on } \\
\text { the operational performance of construction companies. }\end{array}$ & 6 & 0.858 & & 0.759 \\
\hline & Total Areas of Questionnaire & 49 & 0.980 & & 0.925 \\
\hline
\end{tabular}

It is clear from the results shown in Table (8) that the value of the Alpha Cronbach coefficient is high, reaching all fields (0.980), and according to the split method, the results were similar to the Alpha Cronbach method for all areas $(0.925)$.

The questionnaire is therefore in its final form as distributable. The validity and reliability of the research questionnaire have been ascertained, making it reliable for the validity of the questionnaire to analyze the results, and test its hypotheses.

\section{Statistical Methods Used in the Research}

The questionnaire was abstracted and analyzed through the Statistical Package for the Social Sciences (SPSS). The following statistical methods were used:

1- Percentages, frequencies and arithmetic mean: This is used mainly for the purpose of knowing the frequency 
of categories of a variable and is used in the description of the research sample.

2- Cronbach's Alpha test, to determine the stability of the paragraphs of the questionnaire.

3- Split half test to determine the stability of the paragraphs of the questionnaire.

4- Pearson Correlation Coefficient to measure the degree of correlation: This test examines the relationship between two variables. It has been used to calculate internal consistency and structural validity of the questionnaire, and the relationship between variables.

5- $\mathrm{T}$ test in the case of one sample (T-Test) has been used to confirm the mean of each paragraph of the Paragraphs of the questionnaire.

6- Simple Regression Test.

\section{Study Results, Analysis and Discussion}

First: The verification of validity of the first hypothesis of the study hypotheses which states that:

"The contractors in the Gaza Strip have no commitment to the structures of the internal control systems in accordance with the (COSO) model with its elements (control environment, risk assessment, control activities, information and communications, monitoring and follow-up)."

In order to examine this hypothesis, the researcher calculates a matrix of transactions between the elements of internal control system structures according to the (COSO) framework (control environment, risk assessment, control activities, information and communication, monitoring and follow-up).

The results are as shown in Table 9.

Table 9. Matrix of correlation coefficients between the structures of internal control systems according to the (COSO) framework

\begin{tabular}{lllll}
\hline Elements & $\begin{array}{l}\text { Environment } \\
\text { Control }\end{array}$ & $\begin{array}{l}\text { Risk } \\
\text { Assessment }\end{array}$ & $\begin{array}{l}\text { Control } \\
\text { Activities }\end{array}$ & $\begin{array}{c}\text { Information } \\
\text { Communications }\end{array}$ \\
\hline $\begin{array}{l}\text { Environment Control } \\
\text { Risk Assessment }\end{array}$ & $\begin{array}{l}.870^{*} \\
.765^{*}\end{array}$ & $\begin{array}{c}\text { Monitoring } \\
\text { follow-up }\end{array}$ & \\
$\begin{array}{l}\text { Control Activities } \\
\text { Information }\end{array}$ & $.775^{*}$ & $.845^{*}$ & \\
Communications & & $.828^{*}$ & $.770^{*}$ & \\
$\begin{array}{l}\text { Monitoring \& follow-up } \\
\text { Structures of internal }\end{array}$ & $.606^{*}$ & & & \\
control systems & $.896^{*}$ & $.652^{*}$ & $.653^{*}$ & $.730^{*}$ \\
\hline
\end{tabular}

The results indicate that there is a commitment by the construction companies in the Gaza Strip to the structures of the internal control systems according to the (COSO) model. This result demonstrates that this hypothesis is rejected.

The researcher sees that this is due to the fact that these companies have a great interest in the need to adhere to the existence of regular and error-free accounts, and the existence of a proper system of internal control to protect their resources, especially as the size of its work is large, and they are categorized grade (A) in the construction sector.

Second: The verification of validity of the second hypothesis of the study hypotheses which states that:

"There is no statistically significant effect on the implementation of the control environment component according to the (COSO) model on the operational performance of construction companies in the Gaza Strip."

In order to examine this hypothesis, the researcher calculated the arithmetic mean and the relative weight and the order of each paragraph of the second area of the questionnaire regarding the effect of applying the control environment element on the operational performance of the construction companies in the Gaza Strip. 
Table 10. Arithmetic mean and relative weight of the influence of the control environment according to (COSO) model on the operational performance of construction companies

\begin{tabular}{lll}
\hline $\begin{array}{l}\text { First Area: The impact of the Control Environment according to the (COSO) model on the } \\
\text { operational performance of the construction companies }\end{array}$ & $\begin{array}{l}\text { Arithmetic } \\
\text { Mean }\end{array}$ & $\begin{array}{l}\text { Relative } \\
\text { Weight\% }\end{array}$ \\
\hline Total area & 3.57 & 75.05 \\
\hline
\end{tabular}

Table 10 shows that the relative weight of the total area of the effect of the control environment according to the (COSO) model on the operational performance of construction companies was $75.05 \%$ with an average of 3.75 .

In order to understand the impact of the internal control environment in accordance with the (COSO) framework on the operational performance of the construction companies in the Gaza Strip, the simple regression between the paragraphs of the internal control environment according to the (COSO) framework was applied to the operational performance of the construction companies in the Gaza Strip. The results are as shown in the following table:

Table 11. Results of the simple regression between the paragraphs of the control environment according to the framework (COSO) on the operational performance of construction companies in the Gaza Strip

\begin{tabular}{lllllllll}
\hline $\begin{array}{l}\text { Dependent } \\
\text { Variable }\end{array}$ & $\begin{array}{l}(\mathbf{R}) \\
\text { Correlation }\end{array}$ & $\begin{array}{l}\left(\mathbf{R}^{2}\right) \\
\text { Coefficient } \\
\text { Determination }\end{array}$ & of & $\begin{array}{l}\mathbf{F} \\
\text { Calculated }\end{array}$ & $\begin{array}{l}\text { (Sig.) } \\
\text { Significance } \\
\text { Level }\end{array}$ & $\begin{array}{l}\text { Gradient Coefficient } \\
\mathbf{B}\end{array}$ & $\begin{array}{l}\mathbf{T} \\
\text { Calculated }\end{array}$ & $\begin{array}{l}\text { (Sig.) } \\
\text { Significance } \\
\text { Level }\end{array}$ \\
\hline $\begin{array}{l}\text { Operational } \\
\text { performance of } \\
\begin{array}{l}\text { construction } \\
\text { companies }\end{array}\end{array}$ & 0.896 & 0.803 & 239.76 & 0.000 & $\begin{array}{l}\text { Fixed } \\
\text { Amount }\end{array}$ & 0.930 & 5.007 & 0.000 \\
\hline
\end{tabular}

It is clear from the results in Table 11 that the coefficient of correlation was 0.896 and the adjusted factor was 0.803 . This means that $80.3 \%$ of the change in the operational performance of construction companies is due to the effect of the independent variable (control environment), and the rest $(19.7 \%)$ is due to other factors that affect the dependent variable (operational performance).

As a result, this hypothesis of the study is rejected.

The researcher sees that this is due to the awareness of the importance of the control environment and its impact on all other elements of internal control because they represent the cornerstone of the success of internal control, which greatly affects the improvement of the level of operational performance.

This result was in agreement with the results of some studies by Abu Maiala (2013) and (Ayager et al.,2014).

Third: The verification of validity of the third hypothesis of the study hypotheses which states that:

"There is no statistically significant effect of applying the risk assessment component in accordance with the (COSO) model on the operational performance of construction companies in the Gaza Strip."

In order to examine this hypothesis, the arithmetical mean, the relative weight and the order of each of the three areas of the questionnaire were calculated for the effect of applying the control environment component according to the (COSO) model on the operational performance of construction companies in the Gaza Strip. The results are as shown in Table (12):

Table 12. The arithmetic mean and the relative weight of the impact of risk assessment in accordance with the (COSO) model on the operational performance of construction companies

\begin{tabular}{l}
$\begin{array}{l}\text { Second Area: The impact of Risk Assessment in accordance with the } \\
\text { (COSO) model on the operational performance of construction } \\
\text { companies }\end{array}$ \\
\hline Total area
\end{tabular}

Table 12 shows that the relative weight of the total area of the impact of risk assessment according to the (COSO) model on the performance of construction companies reached(75.01\%) and an average of 3.75, This finding 
indicates that the second area paragraphs are largely standards for the operational performance.

In order to understand the impact of risk assessment component according to the (COSO) framework on the operational performance of construction companies in the Gaza Strip, the simple regression between risk assessment paragraphs according to the (COSO) framework was applied to the operational performance of construction companies in the Gaza Strip. The results are as shown in the following table:

Table 13. Results of the simple regression between risk assessment paragraphs according to the framework $(\mathrm{COSO})$ as far as the operational performance of construction companies in the Gaza Strip is concerned

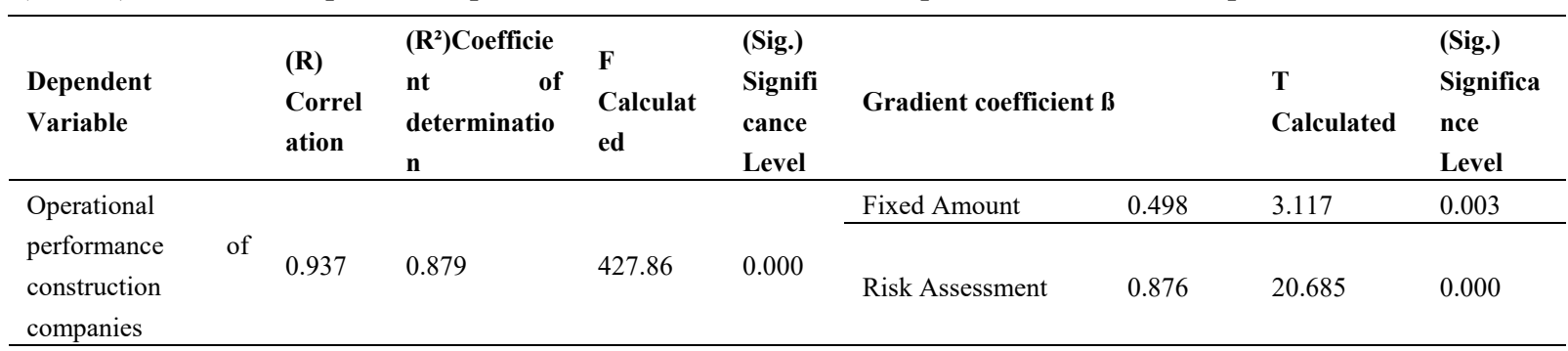

The results indicated in table 13 show that the correlation coefficient reached $(0.937)$ while the coefficient of determination was $(0.879)$. This means that $(87.9 \%)$ of the change in the operational performance of construction companies is due to the independent variable (risk assessment) while the remaining (12.1\%) is due to other factors affecting the dependent variable (operational performance).

The researcher sees that this is due to the understanding and awareness among the respondents that risk assessment is a basis for identifying risks and then managing and dealing with them, which can improve the operational performance by increasing the profit margin.

This result was in agreement with the results of some studies such as that of Lozon (2016), Mushtaha, Muraletharan (2009).

Fourth: The verification of the validity of the fourth hypothesis of the study hypothesis which states that:

"There is no statistically significant impact of the implementation of the control activities component in accordance with the (COSO) model on the operational performance of construction companies in the Gaza Strip."

In order to examine this hypothesis, the researcher calculated the arithmetic average, the relative weight and the order of each of the four areas of the questionnaire regarding the effect of applying the control activities component on the operational performance of construction companies in the Gaza Strip. The results are as shown in Table 14.

Table 14. The arithmetic mean and the relative weight of the impact of the control activities according to the (COSO) model on the operational performance of construction companies

\begin{tabular}{lll}
\hline $\begin{array}{l}\text { Third Area: The impact of Control Activities according to the (COSO) model on the } \\
\text { operational performance of construction companies }\end{array}$ & $\begin{array}{l}\text { Arithmetic } \\
\text { Mean }\end{array}$ & $\begin{array}{l}\text { Relative } \\
\text { Weight } \%\end{array}$ \\
\hline Total area & 3.74 & 74.82 \\
\hline
\end{tabular}

Table 14 shows that the relative weight of the total effect of the control activities according to the (COSO) model on the operational performance of construction companies reached $74.82 \%$ with an average of 3.74 . This finding points to the fact that the areas of the third area constitute a significant measure of the operational performance.

In order to know the impact of the (COSO) control component on the operational performance of Gaza construction companies, a simple regression was used between the paragraphs of the supervisory activities according to the (COSO) model on the operational performance of construction companies in the Gaza Strip. The results are as shown in the following table: 
Table 15. Impact of the simple regression between the paragraphs of control activities according to the framework (COSO) on the operational performance of construction companies in the Gaza Strip.

\begin{tabular}{|c|c|c|c|c|c|c|c|c|c|}
\hline $\begin{array}{l}\text { Dependent } \\
\text { Variable }\end{array}$ & & $\begin{array}{l}(\mathrm{R}) \\
\text { Correl } \\
\text { ation }\end{array}$ & $\begin{array}{l}\left(\mathrm{R}^{2}\right) \\
\text { coefficient of } \\
\text { determinatio } \\
n\end{array}$ & $\begin{array}{l}\text { F } \\
\text { Calculat } \\
\text { ed }\end{array}$ & $\begin{array}{l}\text { (Sig.) } \\
\text { Significa } \\
\text { nce } \\
\text { Level }\end{array}$ & \multicolumn{2}{|c|}{ Gradient coefficient $B$} & $\begin{array}{l}\text { T } \\
\text { calculated }\end{array}$ & $\begin{array}{l}\text { (Sig.) } \\
\text { Significa } \\
\text { nce } \\
\text { Level }\end{array}$ \\
\hline Operational & & & & & & Fixed Amount & 0.751 & 3.828 & 0.000 \\
\hline $\begin{array}{l}\text { performance } \\
\text { construction } \\
\text { companies }\end{array}$ & & 0.897 & 0.804 & 242.55 & 0.000 & Control Activities & 0.811 & 15.574 & 0.000 \\
\hline
\end{tabular}

It is clear from the results in Table 15 that the coefficient of correlation reached $(0.897)$ while the coefficient of determination was $(0.804)$. This means that $(80.4 \%)$ of the change in the operational performance of construction companies is due to the effect of the independent variable (control activities) and that the remaining (19.6\%) is due to other factors affecting the dependent variable (operational performance).

As a result, this hypothesis of the study is rejected.

The researcher sees that this is due to the importance of the role of control activities in ensuring compliance with administrative guidelines, that contribute in increasing income and rationalize costs, and thus improve operational performance.

This result was in agreement with the conclusions of some studies, such as Ayarger \& et al. (2014), Badawi (2011), Al-Sabua (2011) and Muraleetharan (2009).

Fifth: The Verification of the validity of the fifth hypothesis which states that:

"There is no statistically significant impact of the implementation of the information and communication component in accordance with the (COSO) model on the operational performance of construction companies in the Gaza Strip."

To examine this hypothesis, the researcher calculated the arithmetical mean, the relative weight and the order of each paragraph of the fifth area of the questionnaire regarding the impact of applying the information and communication component on the operational performance of construction companies in the Gaza Strip. The results are as shown in Table 16.

Table 16. The mathematical mean and the relative weight of the impact of information and communication area according to the (COSO) model on the operational performance of construction companies

\begin{tabular}{lll}
\hline $\begin{array}{l}\text { Fourth Area: The impact of Information and Communication according to the (COSO) model } \\
\text { on the operational performance of construction companies }\end{array}$ & $\begin{array}{l}\text { Arithmetic } \\
\text { Mean }\end{array}$ & $\begin{array}{l}\text { Relative } \\
\text { Weight } \%\end{array}$ \\
\hline Total area & 3.83 & 76.63 \\
\hline
\end{tabular}

Table 16 shows that the relative weight of the total area of information as well as the communication impact applied according to the (COSO) model on the operational performance of construction companies reached $76.63 \%$ with an average mean of 3.83 , which proves significant as far as the operational performance.

In order to understand the impact of the information and communication component on the (COSO) model applied on the operational performance of construction companies in the Gaza Strip, the simple regression between the information and communication paragraphs according to the (COSO) model was included in the operational performance of construction companies in the Gaza Strip. The results are as shown in the following table: 
Table 17. Results of the simple regression between information and communication paragraphs applied according to the framework (COSO) on the operational performance of construction companies in the Gaza Strip

\begin{tabular}{|c|c|c|c|c|c|c|c|c|c|}
\hline $\begin{array}{l}\text { Dependent } \\
\text { Variable }\end{array}$ & & $\begin{array}{l}\text { (R) } \\
\text { Correlati } \\
\text { on }\end{array}$ & $\begin{array}{l}\left(R^{2}\right) \\
\text { Coefficient } \\
\text { of } \\
\text { Determina } \\
\text { tion } \\
\end{array}$ & $\begin{array}{l}\text { F } \\
\text { Calculat } \\
\text { ed }\end{array}$ & $\begin{array}{l}\text { (Sig.) } \\
\text { Signifi } \\
\text { cance } \\
\text { Level }\end{array}$ & Gradient Coefficient & B & $\begin{array}{l}\text { T } \\
\text { Calculated }\end{array}$ & $\begin{array}{l}\text { (Sig.) } \\
\text { Significa } \\
\text { nce } \\
\text { Level }\end{array}$ \\
\hline \multirow{2}{*}{$\begin{array}{l}\text { Operational } \\
\text { performance } \\
\text { construction } \\
\text { companies }\end{array}$} & \multirow[b]{2}{*}{ of } & \multirow[b]{2}{*}{0.911} & \multirow[b]{2}{*}{0.830} & \multirow[b]{2}{*}{282.23} & \multirow[b]{2}{*}{0.000} & Fixed Amount & 0.508 & 2.595 & 0.012 \\
\hline & & & & & & $\begin{array}{l}\text { Information and } \\
\text { Communication }\end{array}$ & 0.855 & 16.829 & 0.000 \\
\hline
\end{tabular}

It is clear from the results in Table 17 that the coefficient of correlation reached (0.911) while the coefficient of determination was $(0.830)$. This means that $83.0 \%$ of the change in the operational performance of construction companies is due to the impact of the independent variable (information and communications), while the remaining $(17.0 \%)$ is due to other factors affecting the dependent variable (operational performance).

Accordingly, this hypothesis of the study is rejected.

The researcher sees that this is because information and communications provide a database of financial information, that support internal control in achieving its objectives, including the development of operational performance.

Sixth: The verification of the validity of the sixth hypothesis which states that:

"There is no statistically significant impact on the implementation of the monitoring and follow-up component in accordance with the (COSO) model on the operational performance of construction companies in the Gaza Strip"

In order to examine this hypothesis, the researcher calculated the arithmetic average, the relative weight and the order of each paragraph of the fifth area of the questionnaire regarding the effect of applying the monitoring and following-up component on the operational performance of construction companies in the Gaza Strip

Table 18. The arithmetic mean and the relative weight of the monitoring and follow-up monitoring axis according to the (COSO) model concerning the operational performance of construction companies

\begin{tabular}{lll}
\hline $\begin{array}{l}\text { The fifth area: the impact of monitoring and follow-up in accordance with the (COSO) model on } \\
\text { the operational performance of construction companies }\end{array}$ & $\begin{array}{l}\text { Arithmetic } \\
\text { mean }\end{array}$ & $\begin{array}{l}\text { Relative } \\
\text { weight }\end{array}$ \\
\hline Total Area & 3.84 & 76.86 \\
\hline
\end{tabular}

Table 18 shows that the relative weight of the total area of the effect of monitoring and follow-up according to the (COSO) model on the operational performance of construction companies reached $(76.86 \%)$ and an average of 3.84 .This result indicates that the fifth area paragraphs constitute a significant measure of the operational performance.

In order to know the impact of monitoring and follow-up according to the (COSO) model on the operational performance of construction companies in the Gaza Strip, the simple regression between the monitoring and follow-up clauses according to the (COSO) framework was applied to the operational performance of construction companies in the Gaza Strip. The results are as shown in the following table:

Table 19. Results of the simple regression between the paragraphs of monitoring and follow-up according to the framework (COSO) on the operational performance of construction companies in the Gaza Strip

\begin{tabular}{|c|c|c|c|c|c|c|c|c|}
\hline Dependent Variable & $\begin{array}{l}\text { (R) } \\
\text { Correlatio } \\
\mathbf{n}\end{array}$ & $\begin{array}{l}\left(\mathrm{R}^{2}\right) \\
\text { Coefficient of } \\
\text { Determinatio } \\
\mathrm{n} \\
\end{array}$ & $\begin{array}{l}\text { F } \\
\text { calculated }\end{array}$ & $\begin{array}{l}\text { (Sig.) } \\
\text { Significa } \\
\text { nce } \\
\text { Level } \\
\end{array}$ & Gradient Coefficient B & & $\begin{array}{l}\mathrm{T} \\
\text { calculated }\end{array}$ & $\begin{array}{l}\text { (Sig.) } \\
\text { Significanc } \\
\text { e Level }\end{array}$ \\
\hline operational performance & & & & & Fixed amount & 1.165 & 4.751 & 0.000 \\
\hline $\begin{array}{l}\text { of construction } \\
\text { companies }\end{array}$ & 0.816 & 0.666 & 115.79 & 0.000 & $\begin{array}{l}\text { Monitoring } \\
\text { Follow-up }\end{array}$ & 0.681 & 10.761 & 0.000 \\
\hline
\end{tabular}


The results indicated in Table 19 indicate that the coefficient of correlation reached $(0.816)$ and the coefficient was (0.666). This means that $66.6 \%$ of the change in the operational performance of construction companies is due to the independent variable (monitoring and follow-up) (13.4\%) due to other factors affecting the dependent variable (operational performance).

According to this result, this hypothesis of the study is rejected.

The overall results indicate that there is a statistically significant effect on the operational performance of construction companies in the Gaza Strip (control environment - risk assessment - control activities - information and communication - monitoring and follow up).

\section{Conclusion}

The internal control system of any company is the first line in defense that protects the interests of shareholders in particular and all corporate-related parties, providing protection for the production of reliable financial information and making appropriate decisions in investment and credit .

In an "effective" internal control system, the five components of (COSO) model work to support the achievement of an entity's mission, strategies and related business objectives. The components work to establish a solid foundation for internal control within the company through directed leadership, shared values and a culture that emphasizes accountability for control.

The current study sought to identify the impact of the internal control systems according to the (COSO) model with its elements (control environment, risk assessment, control activities, information and communication, monitoring and follow up) on the operational performance of construction companies in the Gaza Strip. The results of the current study found that there is a great commitment of construction companies to the internal control structures of (COSO) model and there is a statistically significant positive effect for each of the elements of the (COSO) model on the operational performance.

\section{Recommendations}

1) The need for construction companies to strengthen internal control systems that are efficient and effective, through the adoption of the structures of their regulatory systems of the elements of the (COSO) model, which contribute to the preservation of the resources of these companies, and protect them from waste and loss.

2) Work on seminars, conferences and workshops to raise awareness of the importance of internal control systems, and their role in the development of operational, financial and strategic performance in companies.

3) Urging those responsible for following up the activities of companies and monitoring them to find the rules and regulations that enable them to know the reality of internal control in companies, and then work to increase efficiency and effectiveness to protect resources, and maximize the role of internal control systems in achieving growth and stability.

4) The need to conduct further studies on other sectors such as services, trade and industry.

\section{References}

Abu-Maiala, S. N. (2017). The impact of the structure of internal control systems in accordance with the (COSO) 2013 model on improving the quality of external audit performance - An analytical study of the external auditors' opinions in the West Bank - Palestine. Journal of Palestine Technical University for Research, $5(1), 1-15$

Al-Bawab, A. (2015). The role of the internal control elements in accordance with the decisions of the (COSO) Committee in improving the performance of the external auditor - a field study on Jordanian Legal accountants. Journal of Administrative Studies, 42(2), 373-388.

Al-Jard, R. B. (2013). The Impact of Evaluation of Internal Control Components on Risk Assessment in Listed Companies in the Damascus Securities Market. Journal of the University, 15(3), 2017.

Al-Sabua, S. S. (2011). The Impact of Internal Control System Structures in accordance with the (COSO) Framework on Control Objectives - The Case of Jordanian Industrial Companies. Studies, Administrative Sciences, 38(1), 103-117.

Al-Sayid, H. M. A. H. (2008). Models of modern internal control in the institution. Journal of Accountants, Kuwait Accountants and Auditors Association, 40.

Al-wardat, K. (2014). The Internal Audit Guide in accordance with IIA International Standards Amman: Al Warraq Publishing and Distribution Est. 
Ammar, T. M. (2015). Internal Control and its Impact on Enhancing Administrative Transparency in Institutions of Higher Education - Gaza Strip, Master Thesis, Faculty of Economics and Administrative Sciences, Al-Azhar University, Gaza.

Arens, A. A., Randal, J. E., \& Mark S. B. (2014). Auditing and Assurance Services, An integrated Approach (15th ed.). Pearson Education Inc.

Ayager, P., Appiah-Gyamerah, I. S. H. M. A. E. L., \& Nartey, J. (2014). The effectiveness of Internal Control Systems of banks. The case of Ghanaian banks. International Journal of Accounting and Financial Reporting, 4(2), 377. https://doi.org/10.5296/ijafr.v4i2.6432

Badawi, A. A. K. (2011). The impact of the structure of the internal control system in accordance with the (COSO) framework on the achievement of the objectives of monitoring - a case study of NGOs in the Gaza Strip. Unpublished Master Thesis, Accounting and Finance Department, Faculty of Commerce, Islamic University of Gaza, Palestine.

Chen, H., \& Shi, Y. (2012). Empirical Study on the Correlation Between the Internal Control and Enterprise Value Based on the Information System. Journal Of Computer, 7(7), 1688-1695. https://doi.org/10.4304/jcp.7.7.1688-1695

Dahdouh, H. A., \& Al-Qadi, H. Y. (2012). Advanced Auditing. Dar Al Thaqafa for Publishing and Distribution, Amman, Jordan.

Harvey, J. (2008). Enterprise Risk Management, The Chartered Institute of Management Accountants. Topic Gateway series No.49. United Kingdom: (CIMA).

Hirth, R. (COSO's) Internal Control-Integrated Framework (2013). Retrieved from http://www.internalauditor.me/ar/ article/cosos-internal-control-integrated-framework

Husseini, M. \& Al-Sai'ri, I. (2017). The use of internal control components to enhance the quality of external auditing - applied research in a sample of Iraqi private banks. Journal of the University of Babylon for Pure and Applied Sciences, 25(4), 1524-1553.

Juma, A. H. (2009). Introduction to Auditing and Modern Emphasis: International Framework-Proof of Audit Findings. Dar Safa for Publishing \& Distribution, Amman, Jordan.

Lozon, H. M. (2016). Effectiveness of Internal Audit Role in Assessing Risk Management according to (COSO) Framework (Applied Study on Government Sectors in the Gaza Strip), Unpublished Master Thesis, Accounting and Finance Department, Faculty of Commerce, Islamic University of Gaza, Palestine.

Muraleetharan, P., (2009). Internal control and impact of financial performance of the organization-Special Reference Public and Private Organizations in Jaffna District. Department of Accounting, University of Jaffna.

Mushtaha, S. M. (2015). Evaluation of Harmonization of Internal Control Systems in Palestinian Public Shareholding Companies with (COSO) Framework and its Impact on Corporate Performance and Value. Al-Azhar University Journal, Human Sciences Series, 17(1).

Palestinian Investment Promotion Agency. (2010). Palestine Investment Guide (2008-2010). Vision of the Future Palestinian State, The Palestine Economic Policy Research Institute (MAS) (3rd ed.). Ramallah, Palestine.

Thunibat, A. A. K., \& Kfous, N. (2012). The extent to which Jordanian industrial joint stock companies comply with internal control requirements and the impact on their financial performance. Journal of Administrative Studies, 39(1), 29-46.

\section{Copyrights}

Copyright for this article is retained by the author(s), with first publication rights granted to the journal.

This is an open-access article distributed under the terms and conditions of the Creative Commons Attribution license (http://creativecommons.org/licenses/by/4.0/). 